Original Research Paper

\title{
The Usage of Biologically Active Raw Materials in Confectionery Products Technology
}

\author{
${ }^{1}$ Alfiya Chernenkova, ${ }^{1}$ Svetlana Leonova, ${ }^{2}$ Tamara Nikiforova, ${ }^{1}$ Anna Zagranichnaya, \\ ${ }^{1}$ Evgeniy Chernenkov, ${ }^{1}$ Olesya Kalugina, ${ }^{1}$ Elena Badamshina and ${ }^{1}$ Igor Gazeev \\ ${ }^{I}$ Federal State Budgetary Educational Establishment of Higher Education, Bashkir State Agrarian \\ University, Ufa, 50-letia Octyabrya str., 34, 450001, Russia \\ ${ }^{2}$ Federal State Budgetary Educational Institution of Higher Professional Education, Orenburg State \\ University, Orenburg, Victory Avenue, 13, 460018, Russia
}

\author{
Article history \\ Received: 16-01-2019 \\ Revised: $15-02-2019$ \\ Accepted: 02-03-2019 \\ Corresponding Author: \\ Alfiya Chernenkova \\ Federal State Budgetary \\ Educational Institution of \\ Higher Professional Education, \\ Bashkir State Agrarian \\ University, Russia \\ Emails: \\ alfia.tchernenkova@yandex.ru, \\ timasheva-1991@mail.ru
}

\begin{abstract}
Increased man-caused impact, imbalance in diets lead to diseases, premature aging and life shortening. To overcome this imbalance, there is an active search for raw materials containing the physiologically functional ingredients necessary for human health or the raw materials containing biologically active substances, vitamins, mineral substances. To enrich traditional recipes with these components and to give functional purpose to products of mass demand, it is advisable to include, oat meal (talcan) and pea meal into the bee-keeping products composition which have a high biological value. Standard methods for analyzing the quality of raw materials and confectionery were used for the study, as well as modern instrumental methods for analysis, such as high performance liquid chromatography and atomic absorption spectrophotometry. The physical and chemical and quality parameters of talcan, pollen pellet, honey and pea meal (by-product of pea processing) have been studied as well as formulas of confectionery products with the indicated components have been developed. The national confectionery dish chak-chak, which recipe included talcan, pollen pellet and honey, contained an increased amount of vitamins and minerals in comparison with the control sample. It has been experimentally proved that the inclusion of these components into the formula allowed obtaining a product with a high nutrient content. It was also found that with the inclusion of pollen pellet into the marshmallow recipe, the amount of vitamins and minerals in the developed product increases. The analysis of the results showed that the enrichment of sugar cookies with pea forage leads to an increase in the content of protein, carotenoids and vitamins. It is established that in comparison with the control sample the content of mineral substances increased.
\end{abstract}

Keywords: Oat Meal (Talkan), Bee-Keeping Products, Pea Meal, Functional Purpose, Bio-Active Raw Material, Confectionary Production

\section{Introduction}

The actual task of population health improvement is to increase the share of functional food intended for healthy and preventive nutrition in the overall structure of massproduced food production. A promising category of food products in this regard is confectionery production which is considered to be an inseparable unit in a modern human diet (Mingaleeva, 2013; Leonova et al., 2016; Sultanova et al., 2018).
Flour confectionery products, cooked in deep fat, as well as traditional sugar cookies are in great demand among the population (Mingaleeva et al., 2016; Chernenkova and Leonova, 2017). The national confectionery includes oriental sweet product chak-chak, which is a deep-fried test dough semi-finished product, filled and 'glued' with honey syrup. A large amount of sugar and fat give the flour confectionary special organoleptic properties. Among the sugary confectionery marshmallows are of considerable interest to consumers. 
However, confectionery products are high-calorie foods, the consumption of which breaks the balance of the diet according to energy value (Chernenkova et al., 2016; Chernenkova and Leonova, 2017). To improve the formula of confectionery products, it is necessary to include raw materials that contain biologically active substances necessary for the human body: vitamins, minerals and dietary fiber.

In search of new natural components used to enrich food products, in recent years special attention is paid to the by-products of grain processing. The creation of enriched food products containing a significant amount of essential macro- and micronutrients in order to improve the health of the population, as well as to prevent diseases, is an important task.

The solution to this problem is possible by expanding the use of grain processing by-products rich in food and biologically active substances. So in Brazil, scientists Freitas and Moretti (2006), developed a formula of high protein and vitamin based cereal bars based on textured soy protein, wheat and oat germ enriched with ascorbic acid and $\alpha$-tocopherol. Also, some works of Croatian researchers at the University of Zagreb are devoted to the study of flour confectionery products with a high content of dietary fiber. Scientists used oatmeal, amaranth, soybean flour and carob flour as natural additives (Šebečić et al., 2007). Argentine scientists have studied the possibility of producing gluten-free sweet snacks with flour from Prosopis alba and flour from the following seeds: 22\% amaranth, 22\% pig weed and $7.8 \%$ quinoa (Sciammaro et al., 2018).

At the University of Zagreb, Croatia, they developed a biscuit recipe with flax seeds. It has been found out that flax enriches biscuits with lignans and omega-3 fatty acid (Cukelj et al., 2016). This product can allow you to replenish the balance of essential nutrients in the human body.

The most common disease caused by the use of cereal proteins is celiac disease. To avoid this disease, scientists Duska Curic and others have developed a recipe for gluten-free bread and bakery products. The formula of these products consisted of cornmeal, defatted soybeans, processed by extrusion at high temperature (Curic et al., 2007). The developments of scientists Dubravka Vitali and others are also known. Biscuit recipes with the addition of amaranth, soybeans and carob fruits have been developed. The results show that $100 \mathrm{~g}$ of such a biscuit can contain from $13.65 \%$ to $37.3 \%$ of daily phosphorus requirements for an adult (800 mg per day) (Dubravka et al., 2007).

With regard to the conditions of the Ural region of the Russian Federation, it is advisable to use not exotic raw materials, but local origin components. To enrich the recipes of confectionery products with biologically active substances and impart a functional trend, it is advisable to include cereal products in the list of ingredients - talcan and pea meal, as well as honey products (Nikiforova et al., 2009; Locmanov et al., 2011; Nikiforova and Hon, 2015; Chernenkova et al., 2016; Tagirov et al., 2018; Leonova et al., 2018).

Based on the above stated, the purpose of the present study is to develop the formula of confectionery products, like chak-chak, marshmallow and sugar cookies, with the addition of biologically active raw materials like talcan, honey, pollen pellet and pea meal.

\section{Materials and Methods}

The studies were conducted in the laboratories of the department of technology of catering and processing of vegetable raw materials of the Bashkir State Agrarian University, Central Analytical Laboratory of the State Scientific Establishment Bashkir Scientific Research Institute of Agriculture and in the laboratory of the Department of Food Production Technology of the Orenburg State University. Clinical trials were conducted at the State Healthcare Institution "Orenburg Regional Clinical Neuropsychiatric Hospital for War Veterans".

When conducting research, we used talcan made from germinated oats and pea meal-which is a highquality raw material, because when processing peas sprout and germ-anatomical parts essential for human get into the flour. We also used pollen load and honey obtained from the Apis m. mellifera L. bee population dwelling in Burzyansky District forests of the Bashkortostan Republic.

Talkan is a cereal product from germinated oat grain. It is rich in an enzyme that helps the absorption of fat in the intestines, as well as polyphenol, which has a positive effect on the liver and pancreas. It also contains an enzyme that helps the absorption of carbohydrates and acts like amylasethe enzyme of the pancreas. The composition of talkan includes minerals necessary for the human body-calcium and phosphorus. In the products of oat processing, it is distinguished from other cereals with high content of fat (5$8 \%$ ), starch $(60 \%)$ and proteins (10-18\%). Also talcan contains B1, B2, B6, D2, D3, E, A, K vitamins, carotene, nicotinic and pantothenic acids, macro- and microelements (potassium, magnesium, iron, chromium, manganese, zinc, nickel, fluorine, iodine, etc.), essential oils (Pogonec and Leonova, 2011; Nuretdinova and Leonova, 2014).

Pea meal is a by-product resulting from the processing of peas into grit. Pea meal is a high-quality 
raw material, because during peas processing, the anatomical parts of the germ-sprout and germ-essential for human get into the flour (Nikiforova et al., 2009).

Pollen pellet is not a bee product exactly, but it is referred to bee-keeping products (Negrão and Orsi, 2018). The pollen collected by the bees is called pollen pellets, as the bee carries it in the baskets of its legs. During the formation of pollen pellet, bees perform wet granulation, covering each grain with agglutinating substances. Pollen pellet consists of pollen grain moistened with nectar. In this regard, the chemical composition of pollen pellet is a mixture of plant and animal origin substances.

According to the scientific literature data, pollen pellet contains a large amount of vitamins: carotene (A); ascorbic acid (C); thiamine (B1); riboflavin (B2); nicotinic acid (B5, PP); pantothenic acid (B3); pyridoxine (B6); biotin (H); folic acid (B9); inosite (B8) and others. Pollen pellet contains minerals the following minerals: $\mathrm{Si}, \mathrm{S}, \mathrm{Cu}, \mathrm{Co}, \mathrm{Na}, \mathrm{Fe}, \mathrm{Al}, \mathrm{Ca}, \mathrm{Mg}, \mathrm{Mn}, \mathrm{P}, \mathrm{Ag}, \mathrm{Ba}$, $\mathrm{Cr}$. The amino acid composition of proteins is represented by alanine, glutamic acid, phenylalanine, tryptophan, cystine, proline, aspartic acid, etc. The pollen pellet contains many nucleic acids and nucleotides, it has pronounced antimicrobial properties, which are due to the content of fatty acids and flavonoid compounds resistant to high temperatures.

Pollen pellet does not cause allergies (Locmanov et al., 2011; Chernenkova et al., 2016; Chernenkova and Leonova, 2017). These data are consistent with foreign sources. Brazilian scientists (Leonova et al., 2015) found that pollen pellet contains 18 amino acids in total, a large amount of protein $(22.80 \pm 3.09 \%)$, flavonoids $\quad\left(2789.87 \pm 1396.00 \mathrm{mcg} 100 \mathrm{~g}^{-1}\right)$, ash $(2.22 \pm 0.39 \%)$ and vitamin C (1.06 $\left.\pm 0.21 \mathrm{mg} 100 \mathrm{~g}^{1}\right)$.

Honey is a complex mixture of water, sugars, enzymes, minerals and vitamins. Fluctuations in its composition and properties depend on the geographical and botanical origin. The main components of honey are carbohydrates that make up $95-99 \%$ of dry matter. The greatest amount of carbohydrates is represented by monosaccharides - glucose and fructose, the percentage ratio of which is $32-36 \%$ and $36-39 \%$, respectively. In honey, the presence of enzymes contained in small amounts - invertase, diastase, catalase, phosphatase, acid and alkaline, glucooxidase, polyphenol oxidase, peroxidase, esterase and a group of proteolytic enzymes. Vitamins found in honey are B1, B2, B3, B5, B6, $\mathrm{C}, \mathrm{E}, \mathrm{K}$, biotin and carotene. Their content is low, but in combination with fructose, glucose, mineral salts, organic acids and biologically active substances, the effect of vitamins is enhanced (Chernenkova and Leonova, 2017; Khaziev et al., 2018; Islamgulov et al., 2018; Mishukovskaya et al., 2018).
The quality of honey was defined according to (GOST R) State Standard of Russia 54644-2011 and DIN 10742-2011. The quality of pollen pellet was defined according to GOST 28887-90 and ONR CEN/TS 16817-1:2016-01, talcan according to TU (Technical Conditions), previously developed at the department of catering technology and vegetable raw materials processing of Federal State Budgetary Educational Institution Bashkir State Agrarian University (Nuretdinova and Leonova, 2014; Leonova et al., 2015).

Physico-chemical and organoleptic quality indexes of finished products was defined according to GOST 24901-2014 and GOST 6441-2014.

The content of fat and water-soluble vitamins was defined by high performance liquid chromatography on a LC-20AD Prominence liquid chromatograph manufactured by Shimadzu (Japan). The method consists in acid and alkaline extraction of vitamins from the samples of the analyzed object, purification from interfering impurities on a polymer sorbent or hexane, separation of vitamins by high performance liquid chromatography on a C18 reverse phase column in a gradient elution mode and their spectrophotometric detection at a wavelength of 260 and $280 \mathrm{Nm}$.

Amino acids were also defined by high performance liquid chromatography on a LC-20AD Prominence liquid chromatograph manufactured by Shimadzu (Japan). The method is based on the cleavage of peptide bonds of protein with hydrochloric acid or alkali when heated, subsequent modification of the resulting amino acids with phenyl isothiocionate, separation of phenylthiocarbamoyl (FTC) amino acid derivatives on a $\mathrm{C} 18$ reversed phase in a gradient elution mode and their spectrophotometric detection at $254 \mathrm{Nm}$.

Minerals were analyzed on a Shimadzu AA-6300 atomic absorption spectrophotometer with an GFA EX7 electro-thermal atomizer (Japan). The method of atomic absorption analysis is based on the property of atoms to absorb radiation of a certain wavelength. Atomic pairs of $\mathrm{Pb}, \mathrm{Cd}, \mathrm{Cu}, \mathrm{Fe}, \mathrm{Mn}, \mathrm{Ni}$ are obtained by heating the sample to a high temperature in a graphite furnace and measure the amount of absorption of radiation of a resonant wavelength by an atomic pair of the element being defined.

The syrup viscosity was defined empirically using a Marsh funnel. The device consists of a measuring cup, a funnel of a certain size and a stopwatch timer. Funnel or Marsh viscosity is the ratio of the rate at which a fluid passes through a hole in a funnel (shear rate). Marsh viscosity is measured in seconds, during which 1 quart $\left(946 \mathrm{~cm}^{3}\right)$ of substance leaves the filled funnel. 


\section{Results}

\section{Analysis of the Properties of Biologically Active Raw Materials}

In the study of the properties of biologically active raw materials, it was found that, according to the organoleptic and physical and chemical parameters the oat talkan corresponded to the $\mathrm{TU}$ (Technical Conditions) requirements. The color is cream; the aroma is not fusty, not musty and no off-aroma, with a slight nutty odor.

The taste is without bitter, sour and other foreign flavors, there is a slight taste of oats. The moisture content of the talkan was $7.3 \%$ (no more than $10 \%$ by Technical Conditions), the ash content was $1.9 \%$ in terms of dry matter. The results of research have established that this product contain $10.8 \%$ of proteins, $6.7 \%$ of fat, $1.7 \%$ of mono - and disaccharides, $58 \%$ of starch and $12.8 \%$ of dietary fiber.

Two categories of water-soluble (C, PP, B3, B6) and fat-soluble (D2, D3, E) vitamins were defined in the talkan. The results are presented in Fig. 1 and 2.

It is established that the following water-soluble vitamins are contained such significant quantities in talcan as ascorbic acid (C)-20.6 mg/kg, nicotinic acid (B3)-19.0 $\mathrm{mg} / \mathrm{kg}$, niacinamide (PP)-95.1 $\mathrm{mg} / \mathrm{kg}$, thiamine hydrochloride (B1)-12.6 mg/kg, as well as fatsoluble vitamins: retinol (A)-3.20 mg/kg, ergocalciferol (D2)-7.70 mg/kg, cholecalciferol (D3)-8,30 mg/kg, tocopherol (E)-10.00 mg/kg.

During the study, an analysis of the number of microelements in talkan was carried out on an atomic absorption spectrophotometer. The results are shown in Table 1.

Analyzing the data obtained, we can conclude that talkan contains minerals in significant amounts: Fe-53.2 $\mathrm{mg} / \mathrm{kg}, \quad \mathrm{Zn}-47.05 \mathrm{mg} / \mathrm{kg}$ and $\mathrm{Cu}-11.7 \mathrm{mg} / \mathrm{kg}$. This indicates the preservation of mineral substances in the finished product and, as a result, allows us to classify the product under development as functional foods.
Summarizing the experimental data obtained, we can make a conclusion that talkan helps to enhance the biological value of flour confectionery products.

In the research, pollen pellet samples were tested for compliance with the requirements of GOST 28887-90. The data presented in Table 2.

Studies of the physical and chemical parameters of pollen pellets confirmed the compliance of the analyzed parameters with the requirements of the specified regulatory documents.

The data on the study of bee pollen collected in the central region of Columbia are known (Fuenmayor et al., 2014). Bee pollen had a moisture content of $7.7 \pm 5.2 \mathrm{~g} / 100$ $\mathrm{g}$ and the following dry matter composition: ash $2.5 \pm 0.4$ $\mathrm{g}$; lipids $6.90 \pm 3.5 \mathrm{~g}$; proteins $23.8 \pm 3.2 \mathrm{~g}$ and he amount of dietary fiber $14.5 \pm 3.5 \mathrm{~g}$, there contained such fatty acids as octadecatrienoic, palmic and linolic. The predominant minerals here were potassium, calcium and magnesium.

The chemical composition of pollen pellet was also studied. The studied pollen pellet contains a significant amount of vitamins $\mathrm{E}, \mathrm{PP}, \mathrm{C}$ and $\mathrm{D}$ and a high concentration of such mineral substances as $\mathrm{Fe}$, $\mathrm{Cu}$ and $\mathrm{Zn}$. (Table 3).

It was established that in the pollen pellet vitamin C content was $2.57 \mathrm{mg} / 100 \mathrm{~g}$, vitamin PP-7.87 mg/100 g, vitamin B3-1.23 mg/100 g, vitamin B6-0.66 mg/100 g, vitamin D2-0.30 mg/100 g and vitamin E- $0.90 \mathrm{mg} / 100 \mathrm{~g}$. The amount of vitamin D3 was not significant. The content of mineral substances was: $\mathrm{Fe}-83.5 \mathrm{mg} / 100 \mathrm{~kg}$, Co- $0.4 \mathrm{mg} / \mathrm{kg}, \mathrm{Cu}-20.0 \mathrm{mg} / \mathrm{kg}$ and $\mathrm{Zn}-67.0 \mathrm{mg} / \mathrm{kg}$.

Table 1: Quantity of mineral elements in talkan

\begin{tabular}{ll}
\hline Microelements & $\begin{array}{l}\text { Quantity, } \\
\mathrm{mg} / \mathrm{kg}\end{array}$ \\
\hline $\mathrm{Fe}$ & 53,2 \\
$\mathrm{Cu}$ & 11,7 \\
$\mathrm{Co}$ & 5,6 \\
$\mathrm{Zn}$ & 47,05 \\
\hline
\end{tabular}

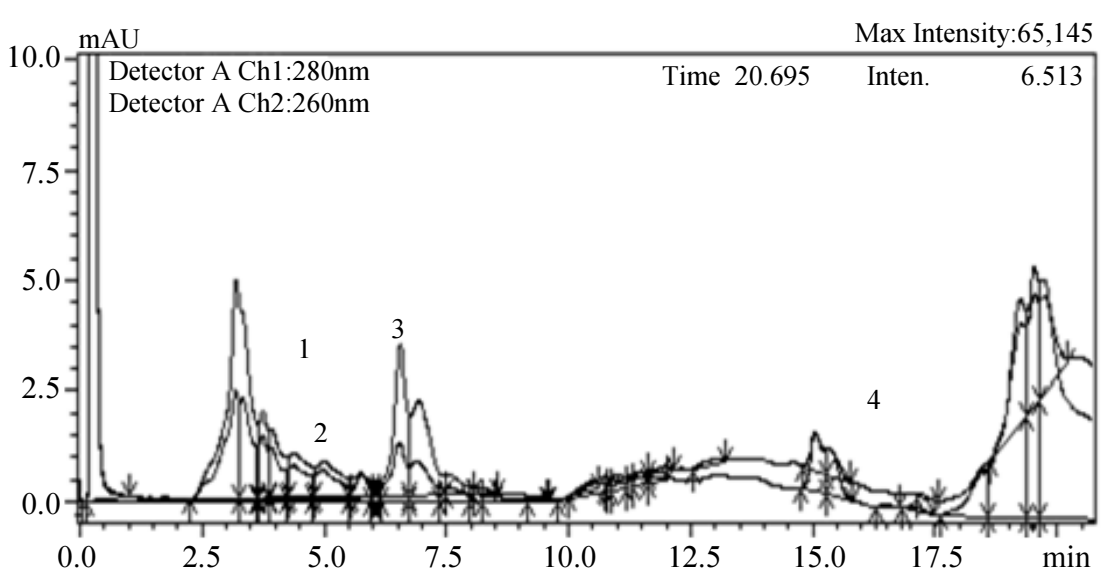

Fig. 1: Water-soluble vitamins content in talcan: 1-ascorbic acid (C); 2-nicotinic acid (B3); 3-niacinamide (PP); 4-thiamine hydrochloride (B1) 


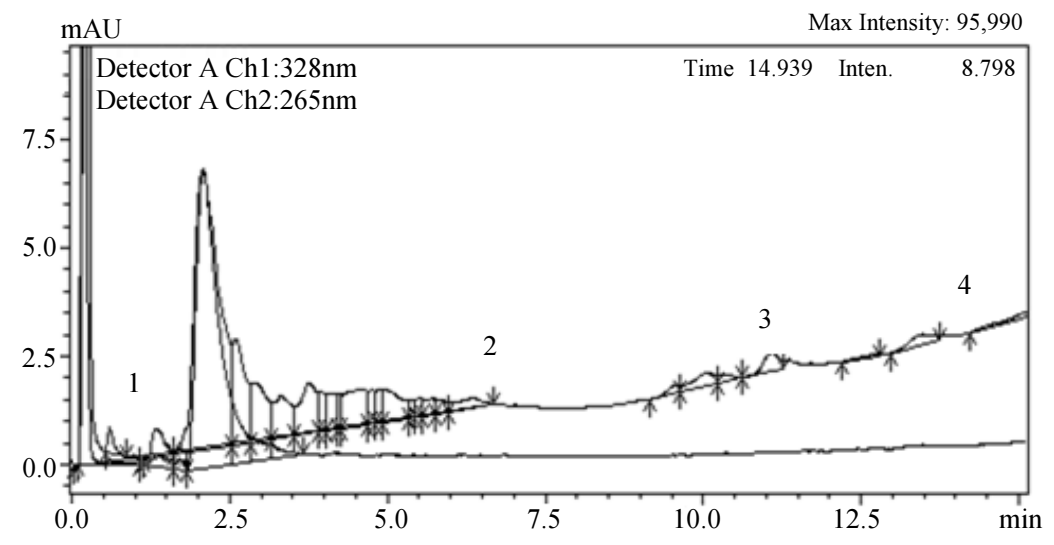

Fig. 2: Fat-soluble vitamins content in talcan: 1-retinol (A); 2-ergocalciferol (D2); 3-cholecalciferol (D3); 4-tocopherol (E)

Table 2: Characteristics and composition of pollen pellet

\begin{tabular}{|c|c|c|}
\hline Parameter name & Characteristics and norms according to GOST 28887-90 & $\begin{array}{l}\text { Pollen pellet } \\
\text { under research }\end{array}$ \\
\hline Product appearance & Granulated mass, fee flowing & Compliant \\
\hline Pellet consistency & $\begin{array}{l}\text { Solid, doesn't knead in fingers, when pressing by solid } \\
\text { object becomes flat and partially breaks into small pieces }\end{array}$ & Compliant \\
\hline Grain size, $\mathrm{mm}$. & $\begin{array}{l}1,0-4,0 \text {. Broken pellets in number not more than } 1,5 \% \\
\text { of test may be present }\end{array}$ & Compliant \\
\hline Color & From yellow to purple and black & Compliant \\
\hline Aroma & Specific, honey-floral, characteristic to pellet & Compliant \\
\hline Flavor & Have spicy, sweety flavor, may have slightly bitter or slightly acid flavor & Compliant \\
\hline Mass fraction of solids, $\%$, not more & 0,1 & 0,08 \\
\hline Moisture content, \% & From 8 to 10 & 8,3 \\
\hline Ash content, \%, не более & 4,0 & 2,6 \\
\hline $\begin{array}{l}\text { Mass fraction of mineral } \\
\text { impurity, } \% \text {, not more }\end{array}$ & 0,6 & 0,1 \\
\hline Poisonous impurities & Should be absent & Absent \\
\hline
\end{tabular}

Table 3: Quantity of vitamins and mineral substances in pollen pellets

\begin{tabular}{|c|c|c|c|}
\hline \multicolumn{4}{|c|}{ Indicator } \\
\hline \multicolumn{4}{|c|}{ water-soluble vitamins $(\mathrm{mg} / 100 \mathrm{~g})$} \\
\hline $\mathrm{C}$ & PP & $\mathrm{B}_{3}$ & $\mathrm{~B}_{6}$ \\
\hline 2,57 & 7,87 & 1,23 & 0,66 \\
\hline \multicolumn{4}{|c|}{ Fat-soluble vitamins (mg/100 g) } \\
\hline A & $\mathrm{D}_{2}$ & $\mathrm{D}_{3}$ & E \\
\hline- & 0,30 & 0,01 & 0,90 \\
\hline \multicolumn{4}{|c|}{ Mineral substances (mg/kg) } \\
\hline $\mathrm{Fe}$ & $\mathrm{Cu}$ & Co & $\mathrm{Zn}$ \\
\hline 83,5 & 20,0 & 0,4 & 67,0 \\
\hline
\end{tabular}

A qualitative analysis of the amino acid composition of pollen pellet by high performance liquid chromatography was conducted. It has been found that there are 11 amino acids in the pollen pellet, 5 of which are essential to the human body. Aspartate acid, glutamic acid, tyrosine, isoleucine, phenylalanine, tryptophan and lysine are also contained in significant quantities.

To define the physical and chemical parameters, quality and composition of honey, we were guided by GOST R 54644-2011. Natural honey is of the following types: monofloral, honeydew and mixed. Floral honey can be monofloral and polyfloral. The botanical origin of monofloral honey is determined by the dominant honey plant. White, sunflower and buckwheat honey is determined in accordance with GOST R 52451.

The type of honey can be defined microscopically by the ratio of structural elements in accordance with GOST R 53878. The results of the honey study used in the development of experimental formulas are shown in Table 4. 
Table 4: Organoleptic and physical and chemical parameters of researched honey

\begin{tabular}{|c|c|c|}
\hline Parameter name & Characteristic and parameter value & Parameters of studied honey \\
\hline Product appearance (consistency) & Liquid, totally or partially crystallized & Compliant \\
\hline Aroma & Pleasant, from subtle to strong, no off- aroma & Pleasant, no off-aroma \\
\hline Flavor & $\begin{array}{l}\text { Sweet, pleasant, with no foreign flavor (for } \\
\text { chestnut honey, tobacco honey and honeydew } \\
\text { honey may have somewhat bitter flavor) }\end{array}$ & $\begin{array}{l}\text { Sweet, pleasant, no foreign } \\
\text { flavor }\end{array}$ \\
\hline Mass fraction of water, $\%$, nor more & 20 & 15 \\
\hline Mass fraction of saccharose, $\%$, not more: & 5 & 3,2 \\
\hline - For floral honey & 10 & \\
\hline - For silver-chain honey & 15 & \\
\hline - For honeydew and mixed honey & & \\
\hline $\begin{array}{l}\text { Mass fraction of } \\
\text { water-insoluble impurities \% not more. }\end{array}$ & & \\
\hline $\begin{array}{l}\text { water-insoluble impurities, \% not more: } \\
\text { - For }\end{array}$ & 0,1 & 0,08 \\
\hline $\begin{array}{l}\text { - For all types of honey, except for press honey } \\
\text { - For press honey }\end{array}$ & 0,5 & \\
\hline Fermentation marks & Should be absent & Absent \\
\hline
\end{tabular}

Table 5: Quantity of vitamins and mineral substances in floral honey

\begin{tabular}{llll}
\hline Parameter & & & \\
\hline Water-soluble vitamins $(\mathrm{mg} / 100 \mathrm{~g})$ & $\mathrm{B}_{3}$ & $\mathrm{~B}_{6}$ \\
$\mathrm{C}$ & $\mathrm{PP}$ & 2,15 & 1,05 \\
2,23 & 5,71 & & $\mathrm{D}$ \\
fat-soluble vitamins $(\mathrm{mg} / 100 \mathrm{~g})$ & & $\mathrm{D}_{3}$ & 0,7 \\
A & $\mathrm{D}_{2}$ & 0,1 & \\
0,4 & 0,2 & & $\mathrm{Zn}$ \\
mineral substances $(\mathrm{mg} / \mathrm{kg})$ & & $\mathrm{Co}$ & 2,05 \\
Fe & $\mathrm{Cu}$ & 0,10 & \\
1,50 & - & & \\
\hline
\end{tabular}

According to the results of organoleptic and physical and chemical parameters, all parameters of the honey studied are compliant with GOST R 54644-2011.

Water and fat soluble vitamins were found in a significant amount in the studied floral honey (Table 5).

It was established that in floral honey the content of vitamin $C$ was $2.23 \mathrm{mg} / 100 \mathrm{~g}$, vitamin PP-5.71 mg/100 $\mathrm{g}$, vitamin B3-2.15 mg/100 $\mathrm{g}$ and vitamin B6-1.05 $\mathrm{mg} / 100 \mathrm{~g}$ it's necessary to note that in floral honey vitamin A was found in the amount of $0.4 \mathrm{mg} / 100 \mathrm{~g}$, there was also vitamin D2 in the amount of $0.2 \mathrm{~m} / 100 \mathrm{~g}$, vitamin D3 of $0.1 \mathrm{mg} / 100 \mathrm{~g}$ and vitamin E- $0.7 \mathrm{mg} / 100 \mathrm{~g}$. It has been found that the floral honey contains such mineral substances as Fe in the amount of $1.50 \mathrm{mg} / \mathrm{kg}$; Co in the amount of $0.10 \mathrm{mg} / \mathrm{kg}$ and $\mathrm{Zn}$ of $2.05 \mathrm{mg} / \mathrm{kg}$.

These data on the analysis of the qualitative and chemical composition of honey in different regions can be compared with the studies of Brazilian scientists. Honey has been found to contain significant amounts of antioxidants, including substances such as carotenoids, enzymes, amino acids, proteins, Maiar reaction products, organic acids and polyphenols, as well as flavonoids and phenolic acids. The carotenoid content in honey, in Mexico, was 0.6-6.2 mg/kg. In the Brazilian semi-arid region of $M$. subnida Duke and Melipona scutellaris Latrelle, the amount of proteins ranged from 0.2 to 0.5 $\mathrm{g} / 100 \mathrm{~g}$, while the levels of proline ranged from 20.5 to $4.6 \mathrm{mg} / \mathrm{kg}$. The total content of the phenolic compound in the honey samples ranged from 1.3 to $126.0 \mathrm{mg}$ equivalent of gallic acid (GAE)/100 $\mathrm{g}$ and flavonoids from $4.2 \pm 0.6$ to $1.9 \pm 0.1 \mathrm{mg} \mathrm{QE} / 100 \mathrm{~g}$ (Ávila et al., 2018).

According to the results of a qualitative analysis of the amino acid composition, it was found that honey contains such essential amino acids as aspartic acid, glutamic acid, alanine, tyrosine. Also found the content of essential amino acids like valine, tryptophan and lysine. We conducted a microscopic analysis of the honey used.

A microscopic analysis of the honey used was carried out according to GOST 31769-2012, which allows defining the type of honey by the ratio of the number of honeydew elements to the number of pollen grains (HE/PG). Table 6 shows the standards for the main types of honey, and table 7 shows the results obtained. Floral honey was used as a control sample, and honey with the addition of the calculated amount of pollen pellet was used as a test sample.

The data obtained indicate that the honey sample belongs to the monofloral floral type. The addition of pollen pellet significantly increases the amount of not only pollen grains, but also of the honeydew elements that enhance the beneficial properties of honey. 
Table 6: Regulations for GOST 31769-2012

\begin{tabular}{ll}
\hline & Ratio \\
Parameter name & HE/PG \\
\hline Floral, less & 1 \\
Mixed & from 1 to 3 \\
Honeydew, not more & 3 \\
\hline
\end{tabular}

Table 7: The ratio of structural elements in honey under microscopic analysis

\begin{tabular}{llll}
\hline & $\begin{array}{l}\text { Quantity of } \\
\text { honeydew elements, }\end{array}$ & $\begin{array}{l}\text { Quantity of } \\
\text { honey grain, } \\
\text { pc per visual field }\end{array}$ & $\begin{array}{l}\text { Ratio } \\
\text { HE/PG }\end{array}$ \\
Sample & pc visual field & 207 & 0,02 \\
Control & 4 & 314 & 0,06 \\
Test & 19 & & \\
\hline
\end{tabular}

Table 8: Contents and composition of sterol in pea meal

\begin{tabular}{ll}
\hline Sterols & $\begin{array}{l}\text { Sterols content, } \\
\text { \% from the sum }\end{array}$ \\
\hline Cholesterol & 2,95 \\
Campesterol & 11,83 \\
Stigmasterol & 4,66 \\
$\beta$-citosterol & 73,21 \\
$\beta$-ampyrone & 7,35 \\
\hline
\end{tabular}

A comprehensive study of the chemical composition of pea meal found that the protein content in it is 20.2$25.5 \%$, fat content is $11.2-14.1 \%$, starch content is $33.6-$ $35.1 \%$, dietary fiber content is $92-14.2 \%$. The ash content of the meal is $3.1-4.5 \%$. The data obtained indicate that the pea meal is a product with high nutritional value.

One of the indicators that determine the biological value of pea grain and its products is the amino acid composition of proteins. In this regard, the amino acid composition of pea meal and pea grain proteins was studied. Studies of the amino acid composition made it possible to state that, in the amount of essential amino acids, pea is superior to whole pea grain. Pea meal is rich in lysine, methionine and cysteine. Based on the data obtained, it can be concluded that the protein complex of the pea meal is more complete than the pea protein in terms of the content of essential amino acids. Studies of the amino acid composition made it possible to establish that the pea meal by the content of lysine, methionine and cysteine exceeds the grain of the pea.

The biological effectiveness of lipids is determined by the qualitative and quantitative composition of fatty acids. In this regard, the fatty acid composition of the pea meal was studied. Studies have shown that the lipid complex of pea meal is widely represented by palmic, oleic, linolic fatty acids and is unsaturated. Linolic acid is the main representative of fatty acids, the amount of which in the pea meal is $36.84 \%$. Pea meal contains polyunsaturated $\omega-3$ fatty acid (4\%).

Studies have been conducted to define the content and composition of sterols of pea meal (Table 8).
The main representative of pea meal sterols is $\beta$ citosterol, which has the highest biological activity.

Carbohydrates are the main source of energy, so their qualitative and quantitative composition in many ways affects the nutritional and energy value of the product. In pea meal, carbohydrates are mainly represented by starch. Studies have shown that apart from starch there is sugar in addition to pea meal. The main sugars of the pea meal are: non-reducing stachios tetrasaccharide (2.6\%), sucrose disaccharide $(0.5 \%)$ and raffinose trisaccharide $(0.7 \%)$. In addition, the carbohydrates of the pea meal are represented by soluble fiber, hemicelluloses and pentosans, which are part of the seed membranes, cell walls and get into the flour during the processing of grain into cereals.

The mineral composition of the pea meal was studied in this research. Studies have shown that the pea meal contains potassium $(1010.0 \mathrm{mg} / 100 \mathrm{~g})$, calcium $(131.0$ $\mathrm{mg} / 100 \mathrm{~g})$, manganese (110.0 $\mathrm{mg} / 100 \mathrm{~g})$, also phosphorus $(288.0 \mathrm{mg} / 100 \mathrm{~g})$, iron $(10.4 \mathrm{mg} / 100 \mathrm{~g})$ and zinc $(31.8 \mathrm{mg} / 100 \mathrm{~g})$. The mineral complex of the pea meal is balanced.

Vitamins are the most important component in any diet. In the process of peeling peas, a significant part of the biologically active substances is converted into byproducts, mostly into the meal. The content of vitamins in the pea meal was also studied. Studies have shown that pea meal contains such most important vitamins as $\mathrm{B} 1$ in the amount of $1.44 \mathrm{mg} / 100 \mathrm{~g}, \mathrm{~B} 2$ in the amount of $0.31 \mathrm{mg} / 100 \mathrm{~g}, \mathrm{~B} 60.60 \mathrm{mg} / 100 \mathrm{~g}$, PP in the amount of $6,20 \mathrm{mg} / 100 \mathrm{~g}$, E in the amount of $8.14 \mathrm{mg} / 100 \mathrm{~g}$ and also carotenoids in the amount of $0.40 \mathrm{mg} / 100 \mathrm{~g}$.

Flavonoids are called 'natural biological reaction modifiers' because of their ability to alter the reaction of the human body to other substances, such as allergens, viruses and carcinogens. This is indicated by their antiinflammatory, anti-allergic, antiviral and anti-tumor properties. Rutin, hyperoside and vitexin were isolated by thin layer chromatography in a pea meal (Table 9).

In connection with the prospect of using the pea meal as a raw material for the food industry, its hygienic state was assessed. The content of pesticides, mycotoxins, radionuclides and toxic elements were studied. The safety assessment of the pea meal showed that it meets the requirements of Sanitary regulations and standards (SanPiN) 2.3.2.1078-01.

Summarizing the data obtained, it can be concluded that the studied types of biologically active raw materials contain significant amounts of waterand fat-soluble vitamins, minerals, as well as essential and non-essential amino acids.

This will significantly increase the phytochemical potential of products with the addition of the above mentioned raw materials and thereby expand the range of flour confectionery products functional purpose. 


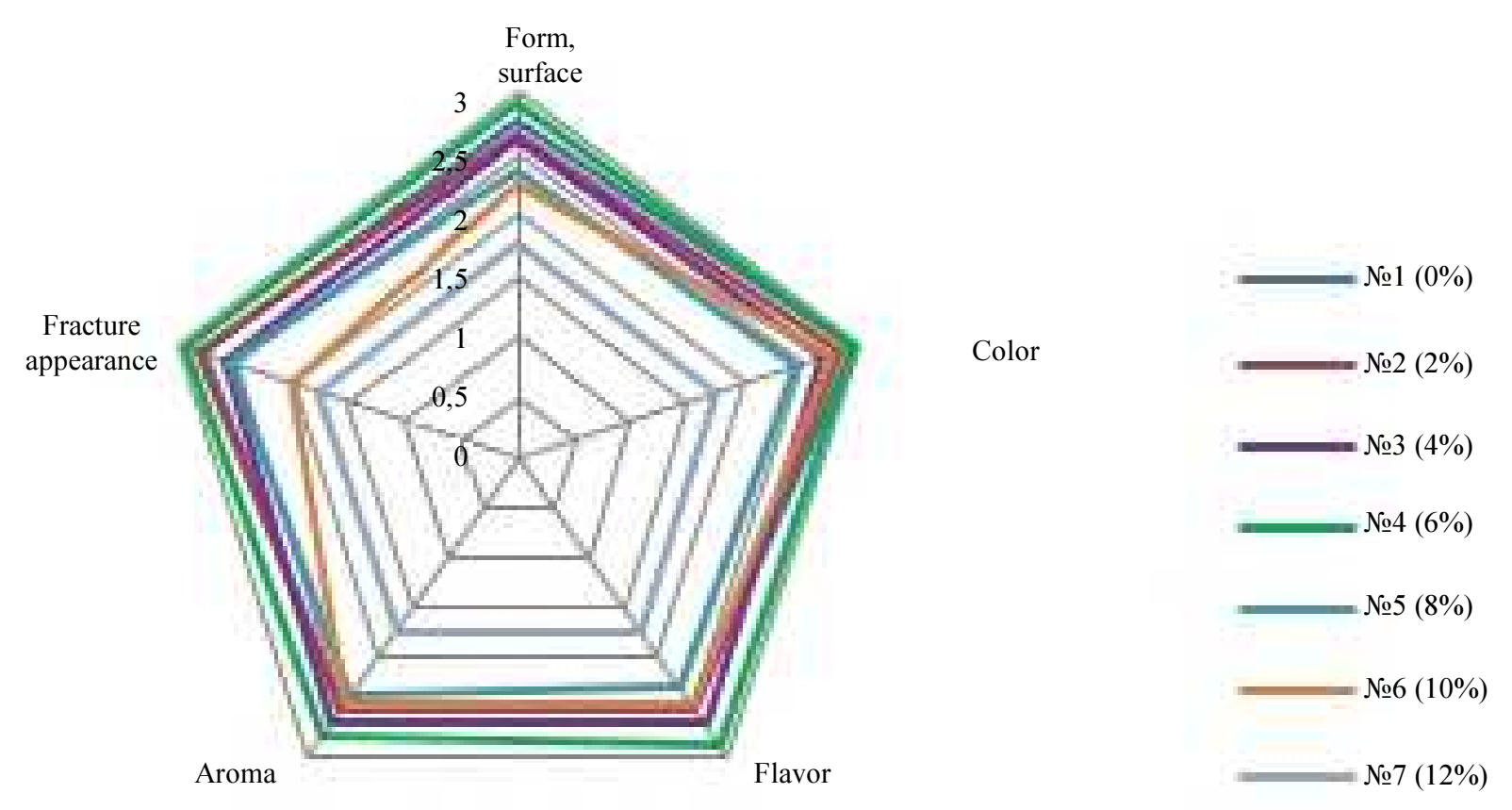

Fig. 3: The effect of talkan dosage on organoleptic parameters of chack-chack

Table 9: Flavonoids content in pea meal

\begin{tabular}{ll}
\hline Flovonoids & $\begin{array}{l}\text { Flavonoids } \\
\text { content, \% }\end{array}$ \\
\hline Rutin & 0,43 \\
hyperoside & 0,04 \\
Vitexin & 0,03 \\
\hline
\end{tabular}

Development of Experimental Formula of Products with the Addition of Biologically Active Raw Materials

Using the traditional recipe of chak-chak, we made experimental samples according to the following scheme:

1. Partial replacement of wheat flour in the recipe with talkan in the amount of: $2 ; 4 ; 6 ; 8 ; 10$ and $12 \%$. Control samples were products without the addition of talkan

2. Partial or complete replacement of sugar by pollen pellet in syrup in the amount of 25; 50; 75 and $100 \%$. Control sample syrup was without added pollen

It was revealed that the greatest preference was given to chuck-chuck with oat talkan with a dosage of $6 \%$ to the mass of flour. Then, they modified the syrup, which the manufactured dough pieces for chak-chak are penetrated (Table 10), carrying out partial or full replacement of sugar by pollen pellet.

It has been established that a high consumer grade was obtained by syrup with a $25 \%$ dosage of pollen pellet to the mass of sugar. The organoleptic, physical and chemical parameters and the amount of vitamins and minerals in the chak-chak were defined (Table 11). The comparison was carried out with a control sample made according to the traditional recipe with no addition of talkan and pollen pellet (see Figure 3).

It has been stated that the chak-chak flour confectionary product contains fat and water-soluble vitamins in the amount of: $\beta$-carotene- $2.4 \mathrm{mg} / \%$; $\mathrm{C}-2.3$ $\mathrm{mg} / \%$; $\mathrm{E}$ is $4.5 \mathrm{mg} / \%$; PP-3.6 mg/\%; B1-2.4 mg/\%; B3$2.2 \mathrm{mg} / \%$. According to the data obtained, a significant amount of mineral substances is present in the product with the addition of talkan and beekeeping products in comparison with the control sample, which indicates their safety in the finished product and, as a result, makes it possible to refer the developed product to functional foods. Thus, the iron content in the prototype was $19.69 \mathrm{mg} / \mathrm{kg}$, copper $-2.20 \mathrm{mg} / \mathrm{kg}$, cobalt- $0.33 \mathrm{mg} / \mathrm{kg}$ and zinc- $11.40 \mathrm{mg} / \mathrm{kg}$. In the product with the addition of talkan and bee products there is a decrease in the mass fraction of fat compared with the control sample. This occurs due to the fact that talkan contains significant amounts of pectic substances that prevent the absorption of fat when products are cooked in deep fat. According to scientific literature data, talkan contains pectin in the amount of $1 \%$, while in wheat flour it is only 0.5\% (Leonova et al., 2015). 
Table 10: Influence of pollen pellet dosage on organoleptic parameters

\begin{tabular}{llllll}
\hline Parameters & Control & $\begin{array}{l}25 \% \text { of } \\
\text { pollen pellet }\end{array}$ & $\begin{array}{l}50 \% \text { of } \\
\text { pollen pellet }\end{array}$ & $\begin{array}{l}75 \% \text { of } \\
\text { pollen pellet }\end{array}$ & $\begin{array}{l}100 \% \text { of } \\
\text { pollen pellet }\end{array}$ \\
\hline Form & 2,9 & 3,0 & 2,6 & 2,0 & 1,6 \\
Color and product appearance & 5,0 & 6,0 & 5,0 & 4,2 & 4,0 \\
Texture and consistency & 7,8 & 9,0 & 6,0 & 5,4 & 3,9 \\
Flavor and aroma & 10,4 & 12,0 & 8,4 & 8,4 & 6,4 \\
Overall assessment $\Sigma$ & 26,1 & 30,0 & 20,0 & 22,0 & 15,9 \\
\hline
\end{tabular}

Table 11: Quality parameters of flour confectionary product chack-chack

\begin{tabular}{lll}
\hline & $\begin{array}{l}\text { Chack-chack made according } \\
\text { to original recipe }\end{array}$ & $\begin{array}{l}\text { Chack-chach enriched with } \\
\text { biologically active raw materials }\end{array}$ \\
\hline Product appearance & Round, from glued dough pieces & Round, from glued dough pieces \\
Color & From light yellow to light-brown & Light-brown \\
Surface & Smooth, consisted from dough pieces & Smooth, consisted from dough pieces \\
Fracture appearance & Evenly baked with small buckling and & Evenly baked with small buckling \\
& holes inside some dough pieces & and holes inside some dough pieces \\
Flavor and aroma & Compliant with the finished product & Compliant with the finished product \\
& with strong honey aroma with no & with strong honey aroma with no \\
Mass fraction of moisture, $\%$ & foreign flavors and aroma & foreign flavors and aroma \\
Mass fraction of fat, \% & 13,0 & 13,0 \\
Mass fraction of sugar, $\%$ & 14,0 & 12,0 \\
Mineral substances quantity, & 28,0 & 29,0 \\
mg/kg: & & \\
Iron & & 19,69 \\
Copper & - & 2,20 \\
Cobalt & - & 0,33 \\
Zinc & - & 11,44 \\
Vitamins quantity, mg/\%: & - & 2,4 \\
$\beta$-carotene & & 2,3 \\
C & 0,03 & 4,5 \\
E & - & 3,6 \\
PP & 0,1 & 2,4 \\
$B_{1}$ & - & 2,2 \\
B $_{3}$ & - &
\end{tabular}

\section{Discussion}

The data we obtained are largely consistent with research conducted both in Russia and abroad. The work of Polish scientists Krystyjan et al. (2015) from the University of Agriculture in Krakow, is known for studying the effect of pollen pellet on the flour confectionery quality properties. Studies have shown that the addition of pollen pellet does not affect the fat content in cookies, the amount of which varies around $21.5 \%$. However, a small but statistically significant increase in the protein and ash content of the product was noted. Also, when adding pollen to biscuits, the content of polyphenols and antioxidant activity was raised 3 times higher compared with the control sample.

Since chak-chak, according to the requirements of TU 9139-022-35559904-2014 should be encashed within 15 days, it was relevant to study the effect of the added components on the change in the shelf life of the product. Since chak-chak contains a large amount of fat, it was appropriate to determine the dynamics of changes in acid and peroxide numbers during storage of products at intervals of three days after analysis. On the following Fig. 4 and 5 you can trace the dynamics of changes in acid and peroxide numbers of fat during storage.

The data obtained clearly demonstrate a decrease in both the acid and peroxide numbers in the test sample. Thus, the peroxide number of fat of the test sample on the 30th day corresponded to the indicator of the control sample on the 9th day of storage. On this basis, the recommended shelf life of the developed product is 30 days.

It was revealed that, thanks to pollen pellet, the color of the chak-chak syrup acquired a noble, rich golden color. The pleasant flavor and aroma characteristic of honey with bee pollen was also noted. In addition, the consistency of syrup has changed.

Figure 6 shows the dependence of the syrup outflow time in the Marsh funnel on the amount of pollen pellet.

There was carried out the analysis of pollen pellet and syrup with pollen pellet on vitamin $\mathrm{C}$ content. It was found out that syrup with the addition of pollen pellet contained ascorbic acid in a significant amount - $47.3 \mathrm{mg}$ per 100 grams of syrup. 

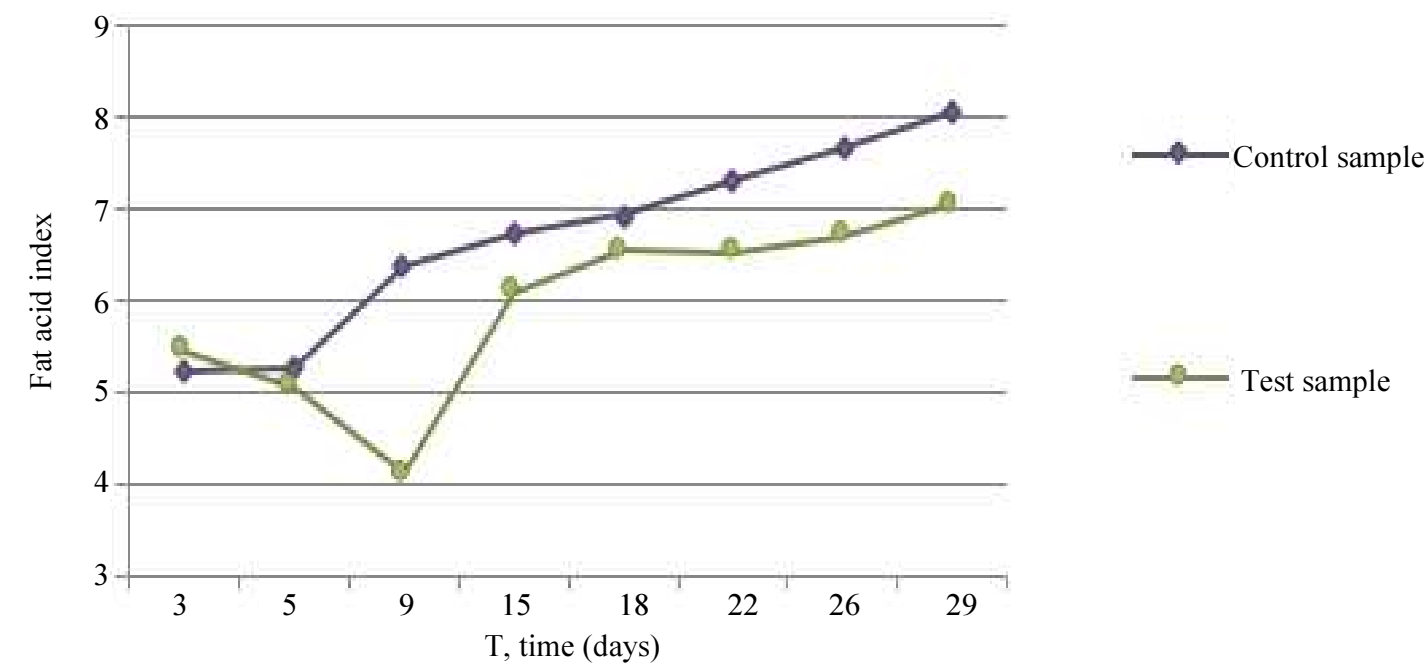

Fig. 4: Dymanics of acid number altering of control and test samples of chack-chack

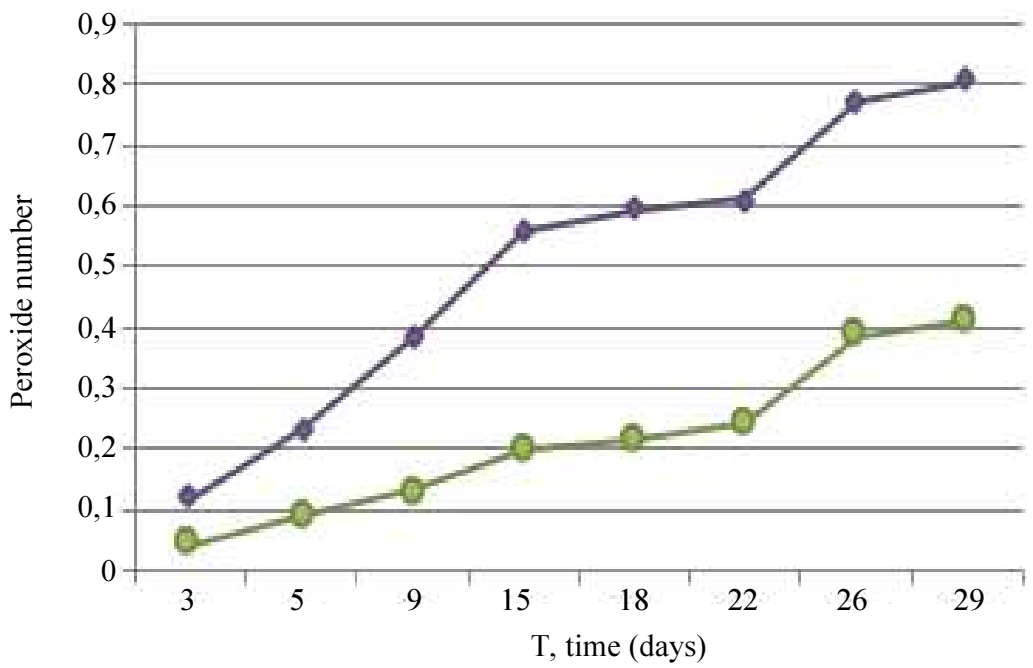

$\longrightarrow$ Control sample

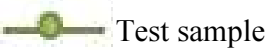

Fig. 5: Dymanics of peroxide number altering of control and test samples of chack-chack
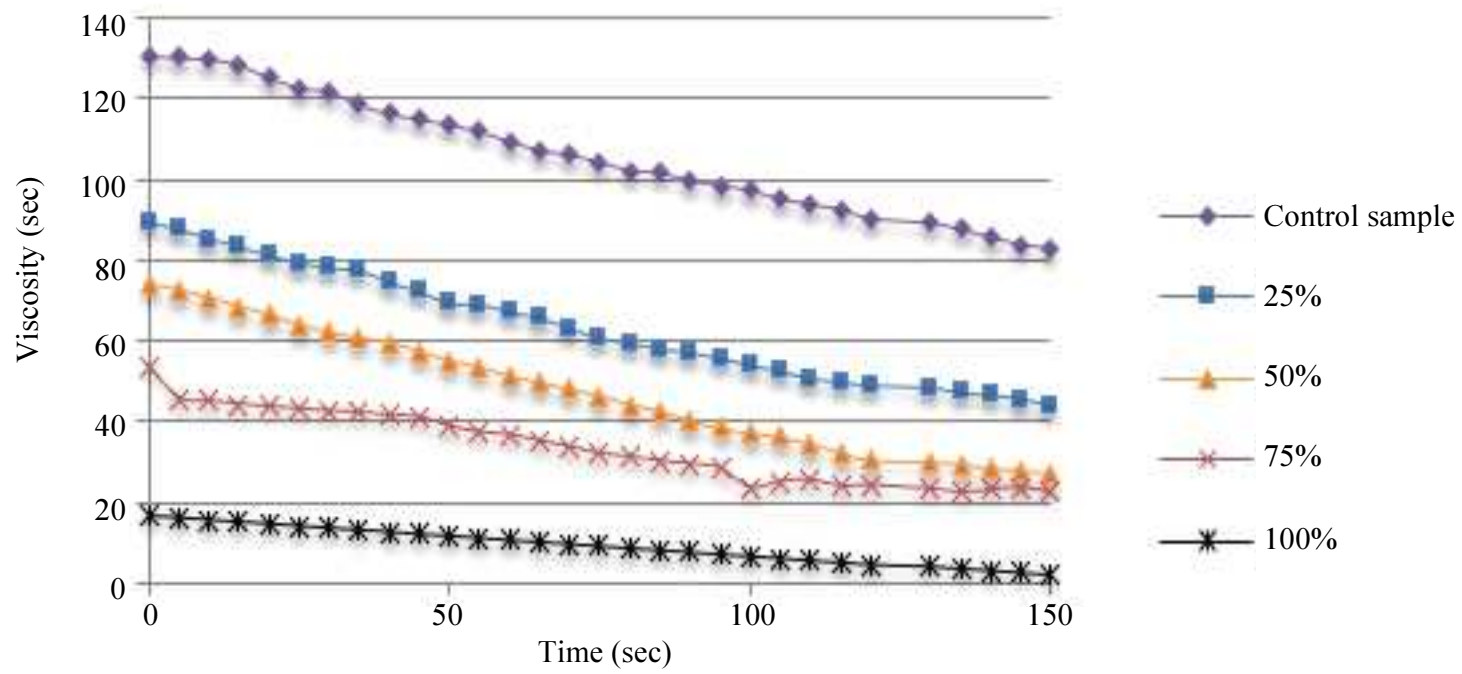

Fig. 6: Dependence of syrup viscosity on pollen pellet content 
Summarizing the data obtained, it can be concluded that talkan, pollen pellet and honey are biologically active raw materials, which not only enriches the product with vitamins, minerals, dietary fiber and amino acids, improves physical, chemical and organoleptic properties. Also, this raw material contributes to an increase in the amount in the developed product. Therefore, chak-chak with the addition of talkan, pollen pellet and honey can be refered to functional products with high phytochemical potential.

A further experiment was devoted to the possibility of using pollen pellet in the recipe of marshmallow. As you know, the recipe of marshmallow and other sugary products contains a large amount of sugar. In this regard, we considered the possibility of replacing sugar in the marshmallow recipe with pollen pellet. In optimizing the dosage of pollen pellets in the marshmallow recipe, the standard recipe was used. Marshmallow samples were made with pollen pellet addition in the amount of $1 \%$; $2 \% ; 3 \% ; 4 \%$ by weight of sugar and a control sample with no addition of pollen pellet.

At the initial stage of the research, a tasting evaluation of manufactured products with different dosages of pollen pellet and a control sample (with no addition of pollen) was conducted to identify consumer demand preferences. As a result of the tasting evaluation, it was found out that a sample with $2 \%$ dosage of pollen pellet was optimal. With a further increase in the dosage of pollen pellet, the organoleptic characteristics of marshmallow decreased. It was noted the appearance of a pleasant honey flavor in the finished products.

With an increase in the dosage of pollen pellets over $2 \%$ the finished products became soft. When defining the solidness characteristics of marshmallow on the ST-2 structure meter using the nozzle 'cylinder $\varnothing 5$ '. The obtained data are presented in Fig. 7. It was established that marshmallow of 1,2 and 3 samples had the best solid characteristics. As the dosage of pollen pellet increased further, the solidness characteristics decreased. This is due to the fact that pollen pellet has high acidity, which negatively affects the rheological characteristics of the product.

The amount of vitamins in marshmallow with the addition of pollen pellet in the optimal dosage (2\%) compared with the control sample was defined. It has been established that vitamin $\mathrm{C}$ is absent in marshmallow with no pollen-pellet addition; $\beta$-carotene is $0.09 \mathrm{mg} / \mathrm{g}$. In marshmallow with the optimal dosage of pollen pellet, the amount of vitamin $\mathrm{C}$ is $2.05 \mathrm{mg} / \mathrm{g}$; $\beta$ carotene is $0.23 \mathrm{mg} / \mathrm{g}$. Consequently, pollen pellet is a biologically active raw material and will help replenish the balance of vitamins in the developed products.

Similar results were obtained in studies conducted at the Latvian Agricultural University. The marshmallow was enriched with bee pollen in an amount of: $1.0 ; 1.5$ and $2.5 \%$. It was established that the respondents gave their preference to $1.5 \%$ dosage of bee pollen samples with (Ungure et al., 2013).

Pea meal is a biologically valuable ingredient that attracts the attention of scientists in different regions of the world. For example, at the Central Research Institute of Food Technologies of India, studies were conducted on the possibility of using pea processing products in the recipe for pasta. Various levels of substitution have been carried out-10, 20 and $30 \%$ of pea flour in noodles.

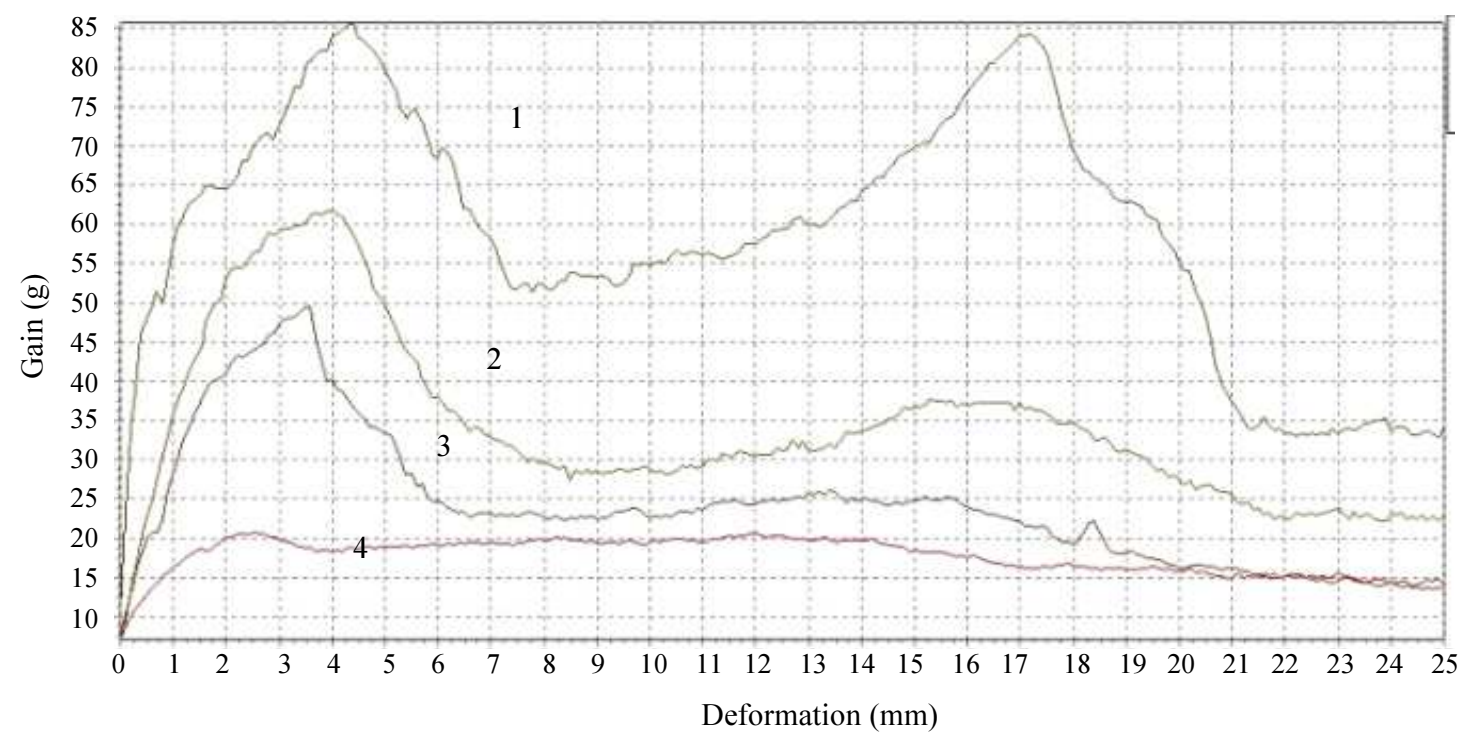

Fig. 7: The result of defining solidness of marshmallow samples: 1-marshmallow with no pollen pellet addition; 2-marshmallow with $1 \%$ substitution of sugar for pollen pellet; 3-marshmallow with $2 \%$ substitution of sugar for pollen pellet; 4 marshmallow with $3 \%$ substitution of sugar for pollen pellet 
The results showed that noodles with $20 \%$ pea flour have favorable organoleptic properties, protein content, good texture, reduced glucose release and increased protein digestibility (Shreenithee and Prabhasankar, 2013). Scientists at the Federal University of Technology, Akure, Nigeria, have developed a recipe for cookies made from a mixture of pea and wheat flour. The results showed that the developed product is rich in dietary fiber, protein and amylose, but has a low glycemic index in combination with a low sugar/starch and amylopectin content (Gbenga-Fabusiwa et al., 2018).

In the development of confectionery formula with the addition of pea meal, the fact that the use of pea processing products is limited due to the presence of anti-nutritional substances and the need for additional processing was taken into account. Modern studies (Zaporozhsky et al., 2016) have shown that the presence of trypsin inhibitors is the strongest anti-nutritional factor in peas. In the course of our experiment, it was established that the activity of trypsin inhibitors of pea meal is $3.86 \mathrm{mg} / \mathrm{g}$. Due to the fact that trypsin inhibitors of pea meal reduce its biological value, the effect of processing methods (granulation, extrusion, IR treatment) on the change in activity of trypsin inhibitors was investigated.

Granulation of the pea meal was carried out on the unit B6-DHA A. In the process of testing we used the matrix with the $12.7 \mathrm{~mm}$ size of the holes. Processing modes were vapor pressure $2 \cdot 105 \mathrm{PA}$, at $\mathrm{T}=140^{\circ} \mathrm{C}$. The temperature of the granules at the exit of the press was $80-85^{\circ} \mathrm{C}$. It is established that granulation of pea meal reduces the activity of trypsin inhibitors to 2.7-2.9 $\mathrm{mg} / \mathrm{g}$. conducted studies have shown that this type of processing helps to stabilize the quality of the pea meal during storage. So, for three months of storage, the acid number of the granulated pea meal has changed from 7.2 to $23.2 \mathrm{mg} \mathrm{KON}$.

In the process of extrusion pea meal was moistened to $14-16 \%$. Tested samples of extruded meal were obtained on a laboratory extruder (rotational speed of the working shaft is $93 \mathrm{rpm}$, processing temperature is $\left.140^{\circ} \mathrm{C}\right)$. The results of the experiment showed a decrease in the activity of trypsin inhibitors to $1.7-2.1 \mathrm{mg} / \mathrm{g}$. It is established that the extrusion of a pea meal also helps to stabilize its quality during storage. The acid number of extruded pea meal over three months of storage was $20.8 \mathrm{mg} \mathrm{KON}$.

We conducted a study of the effect of infrared processing of pea meal with subsequent tempering in the insulating bunker on the activity of trypsin inhibitors. The IR radiation treatment was carried out in a laboratory setup, in which KGT 220-1000 lamps with a radiant flux density of $36 \mathrm{~kW} / \mathrm{m}^{2}$ were used. The processing time ranged from 50 to $90 \mathrm{sec}$, the final treatment temperature was from 80 to $160^{\circ} \mathrm{C}$. The optimal parameters of the infrared processing of the pea meal were set, followed by tempering: the duration of IR heating and tempering was $70 \mathrm{sec}$ and $10 \mathrm{~min}$, respectively. This type of treatment allows reducing the activity of trypsin inhibitors in the pea meal to $0.05-0.07$ $\mathrm{mg} / \mathrm{g}$. In addition, it was possible to stabilize the growth of the acid number during storage. For three months of storage, the acid number of lipids in the IR-treated pea meal was $18.6 \mathrm{mg} \mathrm{KON}$.

Thus, the most effective treatment method for reducing the activity of trypsin inhibitors is the IR treatment of pea meal, followed by tempering in a heat insulating bunker. In connection with the high nutritional and biological value of the pea meal, the possibility of using it in the production of sugar cookies was studied. In the experimental samples of sugar cookies, wheat flour in the standard recipe was partially replaced with pea meal, subjected to IR treatment, followed by tempering. The dosage of the pea meal varied in the range from 5 to $30 \%$. Test laboratory baking was carried out according to standard methods.

During the experiment, it was found that the introduction of pea meal as a component for the production of sugar cookies in an amount from 5 to $25 \%$ (instead of 1 st grade flour), as well as a $9 \%$ reduction in the recipe of margarine does not change the physical and chemical and organoleptic indicators biscuit quality compared to control samples. On the basis of the research conducted, a formula for the Bogatyrskoye sugar cookie was developed using pea meal as a component. Analysis of the results showed that the enrichment of sugar cookies with pea meal up to $25 \%$ leads to an increase in its protein content by 1.2 times. The content of carotenoids in the Bogatyrskoye sugar cookie compared to the control increased by 3 times, B6 vitamins by 1.4 times and PP by 3.5 times.

It was established that in comparison with the control sample, the content of phosphorus, magnesium, calcium and potassium increased by 2.6, 1.3, 3 and 1.7 times, respectively. The amount of iron in the Bogatyrskoe sugar cookies increased 3 times. Thus, the introduction of pea meal as a prescription component of sugar cookies allows you to increase the content of protein, vitamins, dietary fiber and minerals in it, as well as reduce its caloric content.

To substantiate the effectiveness of the use of Bogatyrskoye sugar cookies as a food product for mass consumption, the State Healthcare Institution "Orenburg Regional Clinical Psychoneurological Hospital for War Veterans" conducted comprehensive studies of a group of 18 people aged from 43 to 67 years old.

The effect of the studied products on the course of metabolic processes was assessed by changes in the biochemical parameters of blood, TDP thiamine diphosphate and (FDD) Flavivine Din Dinucleotideeffects before and after taking the Bogatyrskoe sugar cookie. The results of clinical studies indicate that the 
use of the Bogatyrskoe sugar cookie does not cause any disturbances in the metabolic processes in the body of healthy people, as well as elderly people. The use of cookies, enriched with pea meal, contributes to the stabilization of protein, vitamin, mineral and lipid metabolism, as well as the exchange of nitrogencontaining compounds.

No adverse events or any side effects were detected in patients who had Bogatyrskoe sugar cookies for 12 weeks. The results of biomedical assessment of the effectiveness of the use of sugar cookies in the diet with the addition of pea meal showed evidence of positive dynamics in the state of patients in the postoperative period. Thus, Bogatyrskoye sugar cookies can be recommended as a product of therapeutic and prophylactic purposes, both for mass food and for elderly people, as well as patients in the postoperative period.

\section{Conclusion}

It is found that talcan contains such water-soluble vitamins as ascorbic acid (C)-20.6 mg/ $\mathrm{kg}$, nicotinic acid (B3)-19.0 mg/kg, nicotinamide (PP)-95.1 mg/kg, thiamine hydrochloride (B1)-12.6 mg/kg, as well as fatsoluble vitamins Retinol (A)-3.20 mg/kg, ergocalciferol (D2)-7.70 mg/kg, cholecalciferol (D3)-8.30 mg/kg, tocophero $\mathrm{Fe}-53.2 \mathrm{mg} / \mathrm{kg}, \mathrm{Zn}-47.05 \mathrm{mg} / \mathrm{kg}$ and $\mathrm{Cu}-1.7$ $\mathrm{mg} / \mathrm{kg}$ in a significant amount.

It was established that the content of vitamin $\mathrm{C}$ pollen pellet was $2.57 \mathrm{mg} / 100 \mathrm{~g}$, vitamin $\mathrm{PP}-7.87 \mathrm{mg} / 100 \mathrm{~g}$, vitamin B3-1.23 mg/100 g, vitamin B6-0.66 mg/100 g, vitamin D2-0.30 mg/100 $\mathrm{g}$ and vitamin E-0.90 mg/100 g. The amount of vitamin D3 was not significant. Minerals are represented by $\mathrm{Fe}$ in the amount of $83.5 \mathrm{mg} / 100 \mathrm{~kg}, \mathrm{Co}-0.4$ $\mathrm{mg} / \mathrm{kg}, \mathrm{Cu}-20.0 \mathrm{mg} / \mathrm{kg}$ and $\mathrm{Zn}-67.0 \mathrm{mg} / \mathrm{kg}$. It has been found that there are 11 amino acids in the pollen pellet, 5 of which are essential to the human body. Significant quantities contain: aspartic acid, glutamic acid, tyrosine, isoleucine, phenylalanine, tryptophan and lysine.

In the studied floral honey, the content of vitamin $\mathrm{C}$ was $2.23 \mathrm{mg} / 100 \mathrm{~g}$, vitamin PP-5.71 mg/100 g, vitamin B3-2.15 mg/100 g and vitamin B6-1.05 mg/100 g. It should be noted that vitamin $\mathrm{A}$ in the amount of 0.4 $\mathrm{mg} / 100 \mathrm{~g}$ was found in floral honey, vitamin D2 in the amount of $0.2 \mathrm{mg} / 100 \mathrm{~g}$, vitamin D3- $0.1 \mathrm{mg} / 100 \mathrm{~g}$ and vitamin $\mathrm{E}$ were also found in the composition 0.7 $\mathrm{mg} / 100 \mathrm{~g}$. It has been established that the following mineral substances are contained in floral honey: Fe-1.50 $\mathrm{mg} / \mathrm{kg}$; Co- $0.10 \mathrm{mg} / \mathrm{kg}$ and $\mathrm{Zn}-2.05 \mathrm{mg} / \mathrm{kg}$.

It was established that the pea meal consists of protein-20.2-25.5\%, fat-11.2-14.1\%, starch-33.6-35.1\% and dietary fiber-9.2-14.2\% Ash content of the meal is $3.1-4.5 \%$. Pea flour contains potassium $(1010.0 \mathrm{mg} / 100$ g), calcium (131.0 mg/100 g), manganese $(110.0 \mathrm{mg} / 100$ $\mathrm{g})$ and phosphorus $(288.0 \mathrm{mg} / 100 \mathrm{~g})$, iron $(10.4 \mathrm{mg} / 100$ g) and zinc $(31.8 \mathrm{mg} / 100 \mathrm{~g})$, vitamins such as B1 in the amount of $1.44 \mathrm{mg} / 100 \mathrm{~g}, \mathrm{~B} 2-0.31 \mathrm{mg} / 100 \mathrm{~g}, \mathrm{~B} 6-0.60$ $\mathrm{mg} / 100 \mathrm{~g}$, PP-6.20 mg/100 g, E-8.14 mg/100 g and carotenoids $-0.40 \mathrm{mg} / 100 \mathrm{~g}$.

There were developed recipes of confectionery products using the listed ingredients. Their consumer, physical and-chemical, rheological properties and chemical composition were also defined.

It has been established that the chak-chak flour confectionary product contains fat- and water-soluble vitamins in the following amount: $\beta$-carotene- $2.4 \mathrm{mg} / \%$; $\mathrm{C}-2.3 \mathrm{mg} / \%$; E is $4.5 \mathrm{mg} / \%$; PP-3.6 mg/\%; B1-2.4 mg/\%; B3-2.2 mg/\%. There are also in significant quantities are: Iron-19.69 mg/kg, copper- $2.20 \mathrm{mg} / \mathrm{kg}$, cobalt- $0.33 \mathrm{mg} / \mathrm{kg}$ and zinc- $11.40 \mathrm{mg} / \mathrm{kg}$. In the product with the addition of talkan and bee products there is a decrease in the mass fraction of fat compared with the control sample.

An effective method of treating pea agony to reduce the activity of trypsin inhibitors has been found out. It is established that the introduction of pea meal as a component for the production of sugar cookies in an amount from 5 to $25 \%$ (instead of 1st grade flour), physicalchemical and organoleptic indicators of the quality of cookies compared with the control samples are not reduced.

The recipe for the Bogatyrskoye sugar using pea flour as a component cookie has been developed. According to the data obtained, sugar cookies with the addition of pea meal to $25 \%$ leads to an increase in its protein content by 1.2 times, 3 times, vitamins B6-1.4 times, PP-3.5 times, also the amount of phosphorus, magnesium, calcium and potassium increased by $2.6,1.3,3$ and 1.7 times, respectively, compared with the control.

The results of clinical studies indicate that the use of the Bogatyrskoe sugar cookie does not cause any disturbances in the metabolic processes in the body of healthy people, as well as elderly people. Also, the use of cookies, enriched with pea meal, contributes to the stabilization of protein, vitamin, mineral and lipid metabolism, as well as exchange of nitrogencontaining compounds.

Thus, the use of biologically active raw materials as new ingredients components with traditional recipes allows increasing the content of protein, vitamins, dietary fiber and mineral substances in finished products, reducing their caloric content, as well as improving consumer characteristics and giving products functional properties.

\section{Author's Contributions}

Alfiya Chernenkova: Research design and study organization, results interpretation, writing of the manuscript.

Svetlana Leonova: Research design and study organization, results interpretation, final review of the manuscript. 
Tamara Nikiforova: Data analysis and writing of the manuscript.

Anna Zagranichnaya: Analyzing the quality of raw materials and confectionery.

Evgeniy Chernenkov: Data analysis and final review of the manuscript.

Olesya Kalugina: Laboratory experiments, writing of the manuscript.

Elena Badamshina: Research design and laboratory experiments.

Igor Gazeev: Analyzing the quality of raw materials and confectionery inclusion of pollen pellet into the marshmallow recipe.

\section{Ethics}

This article is original and contains unpublished material. The corresponding author confirms that all of the other authors have read and approved the manuscript and there are no ethical issues involved.

\section{References}

Ávila, S., M.R. Beux, R.H. Ribani and R.C. Zambiazi, 2018. Stingless bee honey: Quality parameters, bioactive compounds, health-promotion properties and modification detection strategies. Trends Food Sci. Technol., 81: 37-50. DOI: 10.1016/J.TIFS.2018.09.002

Chernenkova, A.A., E.N. Chernenkov and S.A. Leonova, 2016. The study of amino acid quantity in bee-keeping products to develop recipes for flour confectionary products of functional trend. Innovative technol. technical means for agroidustrial complex.

Chernenkova, A.A. and S.A. Leonova, 2017. The sudy of chemical composition bee-keeping products for developing confectionare products of functional trend. Biotechnol.

Cukelj, N., P. Putnik, D. Novotni, B. Voucko and D. Curic, 2016. Market potential of lignans and omega-3 functional cookies. British Food J., 118: 2420-2433. DOI: $10.1108 / \mathrm{BFJ}-03-2016-0117$

Curic, D., D. Novotni, D. Tusak, I. Bauman and D. Gabric, 2007. Gluten-free bread production by the corn meal and soybean flour extruded blend usage. Agri. Conspec. Sci., 72: 227-232.

Dubravka, V., I.V. Dragojevis, K. Maris and M. Bujan, 2007. Integral wheat flour based biscuits as sources of phosphorus in everyday nutrition. Agri. Conspec. Sci., 72: 245-249.

Freitas, D.G.C. and R.H. Moretti, 2006. Characterization and sensorial evaluation of functional cereal bar [Caracterização e avaliação sensorial de barra de cereais funcional de alto teor protéico e vitamínico]. Ciênc. Tecnol. Aliment., 26: 318-324. DOI: $10.1590 / \mathrm{S} 0101-20612006000200014$
Fuenmayor, C.B., C.D. Zuluaga, C.M. Díaz, M. Cosio and S. Mannino et al., 2014. Evaluation of the physicochemical and functional properties of Colombian bee pollen. Revista MVZ Cordoba, 19: 4003-4014. DOI: 10.21897/rmvz. 120

Gbenga-Fabusiwa, F.J., E.P. Oladele, G. Oboh, S.A. Adefegha and A.A. Oshodi, 2018. Nutritional properties, sensory qualities and glycemic response of biscuits produced from pigeon pea-wheat composite flour. J. Food Biochem., 42: e12505. DOI: $10.1111 / \mathrm{JFBC} .12505$

Islamgulov, D.R., R.R. Ismagilov, A.U. Bakirova, R.R. Alimgafarov and R.G. Yagafarov et al., 2018. Productivity and technological qualities of sugar beet at different times of harvesting depending on contamination and freezing of root crops. J. Eng. Applied Sci., 13: 6533-6540.

Khaziev, D.D., R.R. Gadiev, I. Yu. Dolmatova, A.R. Farrakhov and A.F. Sharipova et al., 2018. Chemical composition and functional-technological properties of mulard meat. J. Eng. Applied Sci., 13: 6413-6418.

Krystyjan, M., D. Gumul, R. Ziobro and A. Korus, 2015. The fortification of biscuits with bee pollen and its effect on physicochemical and antioxidant properties in biscuits. LWT-Food Sci. Technol., 63: 640-646. DOI: 10.1016/J.LWT.2015.03.075

Leonova, S.A., A.A. Chernenkova and T.A. Nikiforova, 2016. The optimization of the stevioside dosage in the recipe of kurnicks.

Leonova, S.A., E.V. Badamshina, E.P. Meleshkina, A.L. Weber and D.T. Gaifullina et al., 2018. Spelta as raw material for food industry and peculiarities of its processing. J. Eng. Applied Sci., 13: 8300-8309.

Leonova, S.A., O.F. Nuretdinova and M.Z. Fazylov, 2015. The technology of national product obtaining from germinated oat grain with apple addition. Bread Productes, 9: 52-53.

Locmanov, A.S., G.I. Nazimova and A.S. Romanov, 2011. The use of bee-keeping products for increasing food value of cakes. Techni. Technol. Food Product., 3: 71-73.

Mingaleeva, Z.S., 2013. Scientific and practical aspects of usingantioxidants in the technology and in the forming consumer properties in the national enriched flour confectionary products. Phd Thesis of Technical Sciences, Moscow.

Mingaleeva, Z.S., L.I. Agzamova, D.E. Morgoshija, Z.Z. Ishakova and O.A. Reshetnik, 2016. Practical aspects of flour confectionary product of functional trend. Proceedings of the 6th International Baltic Sea Forum, (BSF' 16), pp: 1436-1441.

Mishukovskaya, G.S., V.R. Tuktarov, R.K. Avzalov, A.V. Andreeva and D.V. Shelekhov et al., 2018. The influence of mite varroa destructorinfestattion rate on morphometric indicators of apis mellifera 1 . workers. J. Eng.. Applied Sci., 13: 6584-6589. 
Negrão, A.F. and R.O. Orsi, 2018. Harvesting season and botanical origin interferes in production and nutritional composition of bee pollen. Anais Academia Brasileira Ciencias, 90: 325-332. DOI: 10.1590/0001-3765201720150192

Nikiforova, T.A., S.G. Ponomarev, D.A. Kulikov and S.M. Severinenko, 2009. Perspectives of using secondary raw materialfor cereals productions. Bread Products, 2: 50-51.

Nikiforova, T.A. and I.A. Hon, 2015. New type of raw material for functional nutrition. Proceedings of the International Scientific Conference Dedicated to 60th Anniversary of Orenburg State University, (OSU' 15) pp: 281-285.

Nuretdinova, O.F. and S.A. Leonova, 2014. Germinated oat grain as one of the priority types for developing food products of fuctional trend.

Pogonec, E.V. and S.A. Leonova, 2011. Technological propertied characteristics of triticale, of Bashkir tow sort. Grain Product. Russia, 3: 123-134.

Sciammaro, L., C. Ferrero and C. Puppo, 2018. Physicochemical and nutritional characterization of sweet snacks formulated with Prosopis alba flour. LWT, 93: 24-31. DOI: 10.1016/J.LWT.2018.03.019

Šebečić, B., I.V. Dragojević, V. Dubravka, M. Hečimović and I. Dragičević, 2007. Raw materials in fibre enriched biscuits production as source of total phenols. Agri. Conspec. Sci., 72: 265-270.
Shreenithee, C.R. and P. Prabhasankar, 2013. Effect of different shapes on the quality, microstructure, sensory and nutritional characteristics of yellow pea flour incorporated pasta. J. Food Measurement Characterizat., 7: 166-176. DOI: $10.1007 /$ S1 1694-013-9152-5

Sultanova, R.R., K.M. Gabdrahimov, A.F. Khayretdinov, S.I. Konashova and A.K. Gabdelkhakov et al., 2018. Evaluation of Ecological Potential of Forests. J. Eng. Applied Sci., 13: 6590-6596.

Tagirov, H., N.M. Gubaidullin, I.R. Fakhretdinov, F.S. Khaziahmetov and N.V. Gizatova et al., 2018. Carcass quality and yield attributesvof bull calves fed on fodder concentrate "Zolotoi Felutsen". J. Eng. Applied Sci., 13: 6597-6603.

Ungure, E., E. Straumite, S. Muižniece-Brasava and L. Dukaļska, 2013. Attitude and sensory evaluation of marshmallow. Proceedings of the Latvian Academy of Sciences, Section B: Natural, Exact and Applied Sciences, (EAS' 13), pp: 442-447. DOI: 10.2478/prolas-2013-0077

Zaporozhsky, A.A., E.Y.U. Mishkevich and S.P. Zaporozhskaya, 2016. The efficacy of biological treatment to enhance biological value legumes. Scientific Works KubSTU, 14: 710-716. 